GGU et al. 1975: Recipientundersøgelse 1974, Agfardlikavsâ, Qaumarujuk. 108 pp. Copenhagen. Grønlands Fiskeriundersøgelser et al. 1974: Recipientundersøgelse af Qaumarujuk Fjord og Agfardlikavsâ. July - August 1973. 169 pp. Copenhagen.

Vandkvalitetsinstituttet 1972: Recipientundersøgelse af Qaumarujuk Fjord - Agfardlikavsâ. August 1972. 110 pp. Copenhagen.

H.J.B.,

Institut for Petrologi, University of Copenhagen, Øster Voldgade 5-7, 1350 Copenhagen $K$.

\title{
Aeromagnetic surveys in southern and central West Greenland between $63^{\circ}$ and $71^{\circ} \mathrm{N}$
}

\section{Leif Thorning}

A two-year programme of aeromagnetic investigations has been planned for certain areas of West Greenland. The work was started in 1975 from a base camp at Søndre Strømfjord with the majority of the operations taking place in the region south of $67^{\circ} \mathrm{N}$. The airborne measurements of the total intensity of the earth's magnetic field were carried out in co-operation with the party doing radiometric work in the same part of Greenland (Secher, this report). The same aircraft and in part the same instruments were used. Next year, the work will be continued with the main emphasis on the regions north of $67^{\circ} \mathrm{N}$. On completion of the airborne programme follow-up geophysical groundwork will be initiated.

In 1975 more than $30000 \mathrm{~km}$ of magnetic profile were measured (fig. 22). Most of this $\left(25000 \mathrm{~km}\right.$ ) was located in grids covering approximately $40000 \mathrm{~km}^{2}$. At the time of writing most of the digital data is in the process of computer compilation, and only comments based on inflight observations and on inspections of the analogue records can be presented here. This note therefore, deals with the extent of the field work, and points to some of the more obviously interesting features seen in the data.

\section{Instrumentation}

The equipment for the geophysical work was installed in a Britten-Norman Islander aircraft which has an endurance of $6-8$ hours. The equipment consisted of a proton-free precision magnetometer with a stinger mounted sensor, a compensation unit, a radar altimeter, equipment for analogue and digital in-flight registration of total intensity and radar altitude, and a scintillometer. All instruments used the same time base supplied by a quartz clock. The sensitivity of the magnetometer is 1 gamma with a sampling interval of $1 \mathrm{sec}$. Another proton magnetometer of the same sensitivity situated at Søndre Strømfjord served as a base magnetometer. This also supplied analogue and digital registration of the total intensity of the ambient magnetic field and thus provided the necessary record of the diurnal 


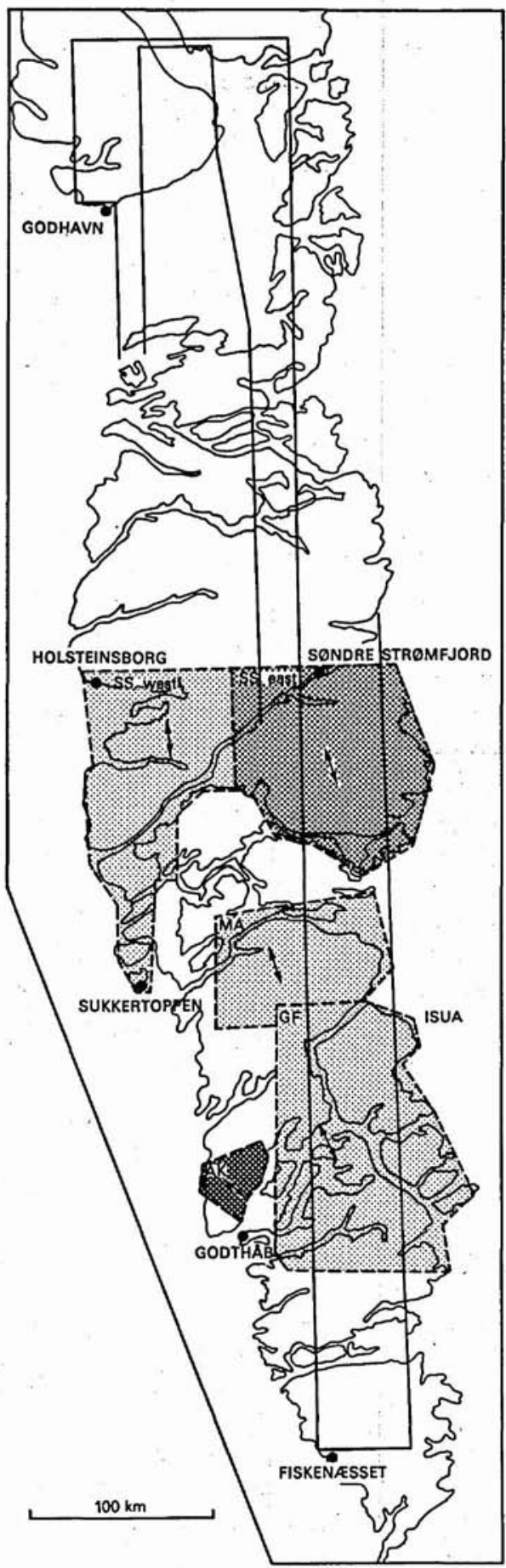

Fig. 22. Aeromagnetic project, 1975, West Greenland. Location of areas covered by grids (shaded to indicate the intensity of the profiles), and some of the longest single profiles outside the grids (solid lines) are shown. In total more than $30000 \mathrm{~km}$ magnetic profile were recorded, with $25000 \mathrm{~km}$ of these placed in the grids covering approximately 40000 $\mathrm{km}^{2}$. 
variations. During operational flights the two quartz clocks worked synchronously and the sampling interval of the base magnetometer was set at $10 \mathrm{sec}$. All instruments performed satisfactorily and the most serious limitations of the work were set by occasional periods of bad weather or severe temporal disturbances in the earth's magnetic field.

\section{Methods}

The main objective of the aeromagnetic surveys is to produce various aeromagnetic maps and profiles (e.g. total intensity, residuals, derivatives, upward and downward continuations) which can be useful in geological mapping work, and which can form the basis of more detailed geophysical work and interpretation on both regional and local scales. Another objective is to use different survey methods and to examine the applicability of such fixed-wing aeromagnetic surveys to the often very rugged and inaccessible terrain of the Precambrian in West Greenland.

All profiles were flown along pre-plotted flight paths by visual navigation, usually at an airspeed of $200-210 \mathrm{~km} / \mathrm{h}$, and with observation points at intervals of $40-60 \mathrm{~m}$. In a few cases the airspeed was reduced in order to get closer spaced observation points. No flights were carried out during magnetic storms or severe disturbances, and some profiles had to be reflown due to the onset of such disturbances. The true positions of the profiles were determined by means of photographs taken with an automatic camera during the flight and later plotted on maps and digitised. All the data were compiled in a data base, which now forms the basis of further processing. The necessary computer facilities for interpretation and presentation of the aeromagnetic data will be built up parallel with the treatment of the data collected this year.

\section{Survey areas}

\section{Godthåbsfjord - Majorqaq}

This region is indicated by the grids GF and MA on fig. 22. A constant barometric altitude of $5000 \mathrm{ft}$ above sea level was maintained throughout the region except in the proximity of a few higher summits in the Godthåbsfjord area. The profiles were spaced at intervals of $2 \mathrm{~km}$ with cross-lines every $25 \mathrm{~km}$.

The aeromagnetic field in the southern part of the area is rather smooth, while further to the north considerable variations in total intensity were detected. By far the largest anomaly is that associated with the banded ironstone formation of the Isua supracrustal belt $\left(65^{\circ} 12^{\prime} \mathrm{N}\right)$ (Allaart, this report). The residual field of the Isua is expected to show anomalies in the order of 20000 to 25000 gammas.

An anomaly of about 1000 gammas was found just north of the glacier of Sarqap sermerssua $\left(65^{\circ} 15^{\prime} \mathrm{N}\right)$, another one (1000-1800 gammas) just south of the river Majorqaq $\left(65^{\circ} 40^{\prime} \mathrm{N}\right)$. Little information is available on the geology of these two regions, but from the general shape of the anomalies it appears that the dominant factor in their generation could be variations in lithology. By similar reasoning a linear striking SW-NE anomaly of the same order of magnitude near the valley of Igassup kua $\left(64^{\circ} 50^{\prime} \mathrm{N}\right)$ is thought to be associated with major faulting. Other major anomalies and many minor ones exist in the area. 


\section{Søndre Strømfjord - Sukkertoppen}

Two different survey methods were employed in this region (marked SS west and east on fig. 22). In the western part, where the relief is very great along the fjords, a constant barometric altitude of $6000 \mathrm{ft}$ was maintained. The distance between profiles was kept at 2 $\mathrm{km}$ with cross-lines every $15 \mathrm{~km}$. East of $51^{\circ} 45^{\prime} \mathrm{W}$ the spacing was reduced to $1.5 \mathrm{~km}$, with $10-15 \mathrm{~km}$ between cross-lines. The altitude was varied from $3000 \mathrm{ft}$ in the north to about 6000 $\mathrm{ft}$ in the south in an attempt to maintain the same average ground clearance over the entire area.

The dominant geological feature of this area is the Nagssugtoqidian boundary which shows up very clearly in the aeromagnetic field. Generally, the total magnetic field intensity increases smoothly northwards from the boundary, whereas south of the boundary, in the pre-Nagssugtoqidian (Archaean) region, the field shows large variations of higher frequencies. Further west the trend is less obvious. In the north-western part of the area the influence of the Holsteinsborg fault system can be seen. The aeromagnetic field across the Nagssugtoqidian boundary will be a major topic of the interpretational work ahead.

\section{Nórdlandet}

The northern part of Nordlandet (marked AK on fig. 22) was flown with profiles $1 \mathrm{~km}$ apart at a barometric altitude of $1500 \mathrm{ft}$. The area is fairly flat and quite suitable for detailed aeromagnetic work and so the airspeed was reduced to get a better resolution of the anomalies. The recorded aeromagnetic field shows many variations presumably associated with structure and lithology so that the results can be expected to be useful in geological mapping.

\section{Additional profiles}

The elongated shape of the region under investigation necessitated a number of long ferry flights. Whenever possible these were placed outside the regions mentioned in the previous sections. Thus some valuable additional profiles were acquired which connected the regions studied in more detail and crossed the ice caps east of Sukkertoppen. One reconnaissance flight was directed north to the Disko Bugt area. By utilising a ferry flight to Fiskenæsset it was possible to produce a single N-S profile along $51^{\circ} \mathrm{W}$ from Boyes Sø on Nûgssuaq in the north to Hellefiskøerne in the south. In addition, by using the landing strip at Marraq for refuelling a number of profiles were flown over the Fiskenæsset region.

The magnetometer system was also kept working on the radiometric flights and in this way an additional $18000 \mathrm{~km}$ of irregular magnetic profiles were recorded. However, because of the unfavourable flight conditions these profiles will only be used for reconnaissance purposes in a qualitative assessment of the areas to be surveyed next year.

\section{Concluding remarks}

The quantitative treatment of the aeromagnetic results has only just begun, but certain data valuable in geological mapping and interpretation, as well as in planning future work, 
have been revealed. It appears that with the present instruments, methods of constant barometric altitude are preferable. Methods attempting a constant average ground clearance are difficult to use for both theoretical and especially practical reasons, and their use should be limited to special cases. In some cases a closer spacing of the profiles would be desirable, but when using visual navigation in terrains like those of West Greenland, the lower limit seems to be at $1 \mathrm{~km}$. Significant improvement of this demands some type of electronic navigational device that provides continuous feed-back of flight path information to the pilot. Finally, the most serious set-back to the work has been the numerous magnetic storms which occur in this part of the world. To overcome this obstacle, the use of a gradiometer system is being considered.

\section{Airborne radiometric survey between $66^{\circ}$ and $69^{\circ} \mathrm{N}$, southern and central West Greenland}

\section{Karsten Secher}

An airborne radiometric survey was initiated in central West Greenland in 1975 following completion of the aeroradiometric work in East Greenland (Nielsen, 1972; Nielsen \& Larsen, 1974). During. 1975 the region between Søndre Strømfjord and Jakobshavn Isfjord was covered, an area of $c .58000 \mathrm{~km}^{2}$. The programme was carried out as a collaboration between GGU and the Danish Atomic Energy Commission's Research Establishment, Risø. GGU and Ris $\varnothing$ each supplied three participants. The aircraft, a Britten-Norman Islander, were chartered through Greenlandair Charter A/S. Aeromagnetic measurements were carried out simultaneously (Thorning, this report). Field operations were carried out from Søndre Strømfjord Air Base.

It is planned to continue this radiometric survey during the next few years, including follow-up fieldwork on the ground.

\section{Equipment and methods}

The aeroradiometric work was carried out using a gamma-ray spectrometer, designed and constructed at Ris $\varnothing$. It is a four-channel spectrometer equipped with six $6 \times 4$ inches $\mathrm{NaI}(\mathrm{T} 1)$ detectors (total volume 11.1 litre). A radar altimeter and an automatic $35 \mathrm{~mm}$ camera were connected to the system. All data were recorded on punched tape, and in addition the count rate in the total count channel, the altitude and the magnetic data were registered on a strip chart recorder. The airspeed was almost constant at $120 \mathrm{~km} / \mathrm{h}$ and the ground clearance was on average kept at $100 \mathrm{~m}$.

The flight routes (about $18000 \mathrm{~km}$ ) followed topographical contours (rim flying) and because of this, they were controlled by distinct morphological features such as fjords, valleys and lakes. It was impossible everywhere to place the flight-lines in a grid-pattern and thus the coverage of the region is rather inhomogeneous. 